\title{
Acute toxicity of nitrite to matrinxã, Brycon cephalus (GüNTHER, 1869), (Teleostei-Characidae)
}

\author{
Toxicidade aguda ao nitrito em matrinxã, Brycon cephalus \\ (GüNTHER, 1869), (Teleostei-Characidae)
}

\author{
Ive Marchioni Avilez ${ }^{1}$ Lucia Helena de Aguiar ${ }^{2}$ Alexandre Eneas Altran ${ }^{3}$ \\ Gilberto Moraes $^{4}$
}

\begin{abstract}
Nitrite leads to many physiological and hematological disturbances followed by lethality. This work reports the lethal concentration of nitrite to juvenile matrinxã. Experiments were done at $24^{\circ} \mathrm{C}, \mathrm{pH}$ 6.7-7.0 under natural photoperiod. Fish were exposed to 0.2-0.5-1.0 and 2.0mg $L^{-1}$ of nitrite $\mathrm{N}-\mathrm{NO}_{2}$ for $96 \mathrm{~h}$. The $96-\mathrm{h}$ LC50 of nitrite- $N$ was calculated by the trimmed Spearman-Karber method $\left(0.86 \pm 0.05 \mathrm{mg} \mathrm{L}^{-1}\right.$; 0.57 1.30 to $95 \%$ CI) and it was concluded that matrinxã is very sensitive to environmental nitrite. Therefore, care must be taken to prevent accumulation of nitrite in intensive culture systems of matrinxã.
\end{abstract}

Key words: LC50, nitrite, matrinxã, Brycon cephalus, toxicity. RESUMO

O nitrito ocasiona vários distúrbios fisiológicos e hematológicos levando à mortalidade. Este trabalho relata as concentrações letais de nitrito em juvenis de matrinxã. Os experimentos foram feitos a $24^{\circ} \mathrm{C}, \mathrm{pH}$ 6,7-7,0 sob foto-período natural. Os peixes foram expostos a 0,2-0,5-1,0 e 2,0mg $L^{-1}$ de nitrito $\mathrm{N}-\mathrm{NO}_{2}$ por 96h. O CL50 96- $h$ de nitrito- $N$ foi calculado pelo método de Spearman-Karber $\left(0,86 \pm 0,05 \mathrm{mg} \mathrm{L}^{-1} ; 0,57-1,30\right.$ para $95 \%$ IC) e concluiu-se que o matrinxã é muito sensível ao nitrito ambiental. Portanto, deve-se ter cuidado em sistemas de cultura intensivo de matrinxã e prevenir o acúmulo de nitrito.

Palavras-chave: LC50, nitrito, matrinxã, Brycon cephalus, toxicidade.

\section{INTRODUCTION}

Several fish from the wild have been domesticated in Brazil and many of them are promising as new species in aquaculture. Among those, the teleost matrinxã (Brycon cephalus, GÜNTHER, 1869), originally from Amazon Basin, has several desirable traits for fish culture, including high growth rate, an appetite for commercial pellets and tolerance of a wide range of temperature and $\mathrm{pH}$. However, information concerning environmental requirements for successful rearing is limited. In addition, basic data on sensitive to environmental toxicants, such as nitrite, are lacking.

Ammonia is the principal nitrogenous excretory product of fish. Its oxidation results in nitrite, an intermediary chemical product of the nitrogen cycle. Nitrite is usually present at low environmental concentrations, but pollution can unbalance the nitrogen cycle leading to elevated values. Chemical residues from industrial activities when dumped in water environments can raise the nitrite levels (NIKINMAA, 1992; HECKMAN et al., 1997). Also, high stocking densities in fish commercial culture systems can lead to nitrite accumulation (DIAB et al., 1993). The increase of water nitrite concentrations can result in many physiological disturbances (HAGOPIAN \& RILEY, 1998; HARGREAVES, 1998).

In the blood, nitrite oxidizes hemoglobin to methemoglobin, a non-functional $\mathrm{Fe}^{3+}$ molecule (CAMERON, 1971; BATH \& EDDY, 1980; JENSEN, 2003), and can be raised in the plasma leading to biochemical changes (BATH \& EDDY 1980; SCHOORE et al., 1995; GROSELL \& JENSEN, 2000) and hematological disorders, as hemolytic

\footnotetext{
${ }^{1}$ Biólogo, Mestre e Doutoranda do Programa de Genética e Evolução da Universidade Federal de São Carlos (UFSCar), SP. ${ }^{2}$ Biólogo, Doutora, UFSCar, São Carlos, SP

${ }^{3}$ Biólogo, Mestre

${ }^{4}$ Biomédico, Doutor, Professor Adjunto, Departamento de Genética e Evolução, UFSCAR. Rod. Washington Luiz, Km 235, 13565-905

São Carlos, SP, Brazil. E-mail: gil@ power.ufscar.br
} 
anemia (SCARANO \& SAROGLIA, 1984; SCARANO et al., 1984). Nitrite also possesses pharmacological properties (JENSEN, 2003) and can be covalently combined to organic compounds resulting in nitro amines, which are very oncogenic derivatives (WOLFF \& WASSERMAN, 1972; HECKMAN et al., 1997). However, the biological activities of nitrite are dependent on whole animal uptake, which are species specific. The goal of this study was to determine the median-lethal concentration (96-h LC50) of nitrite to juvenile matrinxã.

\section{MATERIAL AND METHODS}

Juveniles matrinxã were obtained from the fish farm Águas Claras, Mococa, SP, transported by pick-up to the Adaptive Biochemistry Laboratory, Genetics Department at Sao Carlos University, and stocked in 2,000-L re-circulated, bio-filtered tanks. The water $\left(24 \pm 1.0^{\circ} \mathrm{C}\right.$; $\left.\mathrm{pH} 6.7-7.0\right)$ was continuously aerated and temperature, $\mathrm{pH}$, hardness, oxygen and nitrite were daily monitored. The fish were kept for acclimatization under a natural photoperiod (FebruaryApril), fed on commercial pellets with $35 \%$ protein, two times daily ad libitum, and no nitrite was recorded in the tanks. Feeding was discontinued $24 \mathrm{~h}$ before the initiation of toxicity trials.

Median-lethal concentrations were determined in fiberglass tanks, each containing ten fish and $200 \mathrm{~L}$ of continuously aerated water. At the time of the experimentation the juveniles weighed $45.0 \pm$ $11.85 \mathrm{~g}$. The experiments consisted of a control tank and four concentrations of nitrite. The experiments were conducted in triplicate and results are expressed as percent of mortality. Nominal nitrite (nitrite-N) concentrations (as sodium nitrite) in the tanks were $0.2,0.5,1.0$ and $2.0 \mathrm{mg} \mathrm{L}^{-1} \mathrm{~N}-\mathrm{NO}_{2}$. Water was renewed every $24 \mathrm{~h}$ and nitrite was added to maintain the initial concentration in a semi-static system for $96 \mathrm{~h}$. Fish were not fed during the experiment and dead fish were daily removed. Fish mortality was recorded and the 96-h LC50 $\mathrm{N}-\mathrm{NO}_{2}$ was calculated by the trimmed Spearman-Karber method (HAMILTON et al., 1978). Water quality was monitored every day in the course of the experiment. Ammonia was determined by nesslerization modified from GENTZKOW \& MASEN (1942). Hardness was determined by titration with eriochrome black and expressed as $\mathrm{mg}$ of $\mathrm{CaCO}_{3}$ $\mathrm{L}^{-1}$ (APHA, 1980). Temperature and oxygen levels were determined to the nearest $1^{\circ} \mathrm{C}$ and $0.1 \mathrm{mg} \mathrm{L}^{-1}$ respectively, with an oxygen-temperatureconductivity-pH meter Check Mate II Corning. The median temperature of water $\left(23 \pm 0.9^{\circ} \mathrm{C}\right)$ and the oxygen level $\left(5.9 \pm 0.21 \mathrm{mg} \mathrm{L}^{-1}\right)$ were constant. A slight increase of hardness and conductivity was observed but these changes were not significant. There was a rise in $\mathrm{pH}$ likely attributed to ammonia released by the fish (Table 1). Alkalinity was determined by sulfuric titration (GOLDSTEIN \& CLYMO, 1969) and no changes were observed. Chloride concentration was determined as APHA (1980). Water nitrite concentrations were determined with sulfanilamide and N-1 (naphtyl) ethylenediamine bichloridrate at 540nm (TAVARES, 1994). Nitrite concentrations were constant in the experimental tanks and practically absent in the control. Because fish nitrite responses are different among the species, a wider range of nitrite concentrations was previously tested to determine the present range for the LC50 assay.

\section{RESULTS AND DISCUSSION}

To date, the maximum nitrite concentration allowed for environmental waters in Brazil is $1.0 \mathrm{ppm}$ pursuant to CONAMA resolution, nํำ 20 (BRASIL, 1986). Matrinxã was revealed to be very sensitive to nitrite. The 96-h LC50 of nitrite-N to juvenile matrinxã was $0.86 \pm 0.05 \mathrm{mg} \mathrm{L}^{-1}(0.57-1.30 ; 95 \% \mathrm{CI})$. All fish survived in the control tank. One, two, nine and ten fish died in the $0.2,0.5,1.0$ and $2.0 \mathrm{mg} \mathrm{L}^{-1} \mathrm{~N}-\mathrm{NO}_{2}$ treatments, respectively (Table 1 ). The range of sensitivity to environmental nitrite is very wide among fish. These differences may be related to environmental adaptations and/or organismal traits (LEWIS \& MORRIS, 1986; ARANA, 1997). The 96-h LC50 of nitrite-N of channel catfish Ictalurus punctatus is 7 $\mathrm{mg} / \mathrm{L}$ (PALACHEK \& TOMASSO, 1984). The rainbow trout Onchorinchus mykiss tolerates $0.24 \mathrm{mg}$ $\mathrm{L}^{-1}$ at $10^{\circ} \mathrm{C}$ whereas Onchorinchus tschawytscha survives at $4.7 \mathrm{mg} \mathrm{L}^{-1}$, and the tolerance of Micropterus salmoides reaches $140 \mathrm{mg} \mathrm{L}^{-1}$. However, the rainbow trout in brackish water tolerates $22 \mathrm{mg} \mathrm{L}^{-1}$ (RUSSO \& THURSTON, 1977). Tambaqui, Colossoma macropomum, a Neotropical fish from Amazonia is very sensitive to nitrite. Its $96-\mathrm{h} \mathrm{LC50} \mathrm{is} 0.54 \mathrm{mg} \mathrm{L}^{-1}$ nitrite $\mathrm{N}-\mathrm{NO}_{2}$ (COSTA et al., 2004). There are very few data on the nitrite toxicity in Amazonian fish. The wide biodiversity observed in the Amazon and the potential of the species for aquaculture drive the studies concerning their environmental characteristics very relevant. The level of environmental chloride is important in determining the toxicity of nitrite to fish. Chloride competes with nitrite at the level of chloride cell of the gills (GAINO et al., 1984).

High concentrations of chloride ions reduce the toxicity of nitrite. Seawater fish are usually less

Ciência Rural, v.34, n.6, nov-dez, 2004. 
sensitive to nitrite than freshwater fish. The 96-h LC50 of nitrite-N for European eel Anguilla anguilla can range from $84.0 \mathrm{mg} \mathrm{L}^{-1}$ in freshwater to $812.0 \mathrm{mg} \mathrm{L}^{-1}$ in full strength seawater (salinity $=36.0 \mathrm{mg} \mathrm{L}^{-1}$ ) to the ability of some species to exclude the nitrite entry at the gill membrane. Some species lack this ability and actually concentrate nitrite in the plasma when it is present in the environment. This uptake is proposed to be an active mechanism (PERRONE \& MEADE, 1977; PALECHEK \& TOMASSO, 1984). Another hypothesis assumes that the inter-specific differences in nitrite resistance lie in chloride influx rates (WILLIAMS \& EDDY, 1986). Species with higher influx rates have concomitantly higher nitrite uptake rates. These species should be more susceptible to nitrite toxicosis in lower nitrite environmental concentrations. The chloride ion should compete with nitrite uptake at the gill surface. Therefore, the response of freshwater fish to nitrite is very dependent on the type of water (EDDY et al., 1983; GAINO et al., 1984). Our study was conducted in low levels of chloride $(0.010 \pm 0.0016 \mathrm{mM})$, and they were kept constant at values near the natural freshwater environment. Brazilian continental waters are ion-poor and have low $\mathrm{Cl}^{-}$concentrations (ESTEVES, 1988). Amazonian waters vary from $0.0006 \mathrm{mM}$ in the Negro River to $0.089 \mathrm{mM} \mathrm{Cl}^{-}$in Solimões River (FURCH, 1984). Most Amazonian rivers possesses low levels of the major ions, and chloride concentration is also low (VAL \& HONCZARYK, 1995). Matrinxã originated from very soft water and the high nitrite sensitivity observed in matrinxã was expected.

Other ions also influence the rate of nitrite uptake in fish. The hybrid sunshine bass (female Marone chrysops x male M. saxatilis) is protected (SAROGLIA et al., 1981). This has been attributed

against nitrite toxicity by environmental chloride; however, the addition of $250 \mathrm{mg} \mathrm{L}^{-1}$ of $\mathrm{Ca}^{2+}$ (as chloride) was about seven times more effective to restrain nitrite uptake (WEIRICH et al., 1993). Therefore, concentrations of nitrite and water quality are quite related, and are particularly relevant in fish culture conditions. No relevant data are supplied concerning the effects of environmental nitrite- $\mathrm{N}$ on the growth rate of fish, when the concentrations are lower than the 96h LC-50. Nevertheless, the use of chloride in fish culture systems may alleviate toxic effects of nitrite. The $96 \mathrm{~h}$ LC-50 for nitrite-N established in matrinxã shows it is very sensitive. For that reason special attention must be paid to the critical levels of nitrite in order to prevent acute toxicity for the species in intensive culture systems. Further studies are necessary to investigate the protective effect of $\mathrm{Cl}^{-}$and other ions such as $\mathrm{Ca}^{2+}$ on nitrite toxicity in matrinxã.

\section{ACKNOWLEDGEMENTS}

This research was supported by the Brazilian research funding institution, $\mathrm{CNPq}$, and FAPESP. The authors would like to thank Mr. Antônio Aparecido Donizete and friends of the Biochemistry Adaptation Laboratory for supporting this work.

\section{REFERENCES}

APHA. Standard methods for examination of water and wastes. 12. ed. Washington, DC : Join Editorial board, 1980.

ARANA, L.V. Princípios químicos da qualidade de água em aquiicultura. Florianópolis : UFSC, 1997. 166p.

BATH, R.N.; EDDY, F.B. Transport of nitrite across fish gills. Journal of Experimental Zoology, v.214, n.1, p.119-121, 1980.

BRASIL. Conselho Nacional do Meio Ambiente. Portaria n. 20, de 30 de julho de 1986. Diário Oficial [da República Federativa do Brasil], 1986.

Table 1 - Water quality during exposure of juvenile matrinxã to environmental nitrite nitrogen (nitrite-N). Values for hardness, conductivity and ammonia are mean $\pm \mathrm{SD}$, and values for $\mathrm{pH}$ are ranges.

\begin{tabular}{lcccccc}
\hline $\begin{array}{l}\mathrm{N}-\mathrm{NO}_{2} \\
(\mathrm{mg} / \mathrm{L})\end{array}$ & $\begin{array}{c}\text { Time } \\
(\mathrm{h})\end{array}$ & $\begin{array}{c}\text { Percent } \\
\text { mortality }\end{array}$ & $\begin{array}{c}\text { Hardness } \\
(\mathrm{mg} / \mathrm{L})\end{array}$ & $\begin{array}{c}\text { Conductivity } \\
\left(\mu \mathrm{S} / \mathrm{cm}^{3}\right)\end{array}$ & $\begin{array}{c}\mathrm{NH}_{3}-\mathrm{NH}_{4}{ }^{+} \\
(\mathrm{mg} / \mathrm{L})\end{array}$ & $\mathrm{pH}$ \\
\hline \multirow{2}{*}{ Control } & 0 & 0 & $18 \pm 0.5$ & $63.7 \pm 0.03$ & $0.2 \pm 0.01$ & $6.0-6.4$ \\
& 96 & 0 & $27 \pm 1.1$ & $72.3 \pm 0.04$ & $1.7 \pm 0.02$ & $6.2-6.6$ \\
0.2 & 0 & 0 & $25 \pm 1.3$ & $66.0 \pm 0.04$ & $0.4 \pm 0.01$ & $7.8-8.0$ \\
& 96 & 10 & $29 \pm 1.6$ & $74.3 \pm 0.03$ & $1.6 \pm 0.02$ & $7.3-7.7$ \\
0.5 & 0 & 0 & $28 \pm 1.2$ & $70.0 \pm 0.05$ & $0.3 \pm 0.02$ & $7.6-7.7$ \\
& 96 & 20 & $29 \pm 1.6$ & $76.8 \pm 0.02$ & $1.6 \pm 0.02$ & $7.6-7.8$ \\
1.0 & 0 & 0 & $23 \pm 0.1$ & $75.0 \pm 0.04$ & $0.4 \pm 0.02$ & $6.1-6.3$ \\
& 96 & 90 & $35 \pm 0.9$ & $79.1 \pm 0.03$ & $1.2 \pm 0.02$ & $6.4-6.6$ \\
2.0 & 0 & 0 & $23 \pm 0.5$ & $86.0 \pm 0.04$ & $0.3 \pm 0.01$ & $6.5-6.7$ \\
& 96 & 100 & $25 \pm 1.0$ & $88.3 \pm 0.02$ & $0.7 \pm 0.02$ & $6.6-6.8$ \\
\hline
\end{tabular}

CAMERON, J.N. Methemoglobin in erythrocytes of rainbow trout. Comparative Biochemistry and Physiology, Part A, v.40, p.743-749, 1971

COSTA, T.F.C. et al. Susceptibility of the Amazonian fish, Colossoma macropomum (Serrasalminae), to short-term exposure to nitrite. Aquaculture, v.232, p.627-636, 2004.

DIAB, S. et al. Nitrification pattern in a fluctuating anaerobic-aerobic pond environment. Water Reserch, v.27, n.9, p.1469-1475, 1993.

EDDY, F.B. et al. Uptake and loss of nitrite from the blood of rainbow trout, Salmo gairneri (RICHARDSON), and Atlantic salmon, Salmo salar L. in fresh water and dilute sea water. Journal of Fish Biology, v.23, p.105-116, 1983. 
ESTEVES, F.A. Fundamentos de limnologia. Rio de Janeiro : Interciência FINEP, 1988. 575p.

FURCH, K. Water chemistry of the Amazon : the distribuition of chemical among freshwater. In: SIOLI, H. (Ed.). The amazon limnology and landscape ecology of a mighty tropical river and its basin. Junk : the Hague, 1984. p.167-199.

Gaino, E.; Arillo, A.; Mensi, P. Involvement of the gill chloride cells of trout under acute nitrite intoxication. Comparative Biochemistry Physiology Part A., v. 77, n. 4, p. 611-617, 1984.

GENTZKOW, C.J.; MASEN, J.M. An accurate method for the determination of blood urea nitrogen by direct nesslerization. Jounal of Biology and Chemistry, v.143, p.531-544, 1942.

GOLDSTEIN, E.G.; CLYMO, R.S. Methods for chemical analysis of freshwater. Oxford : Blackwell Scientific, 1969. 171p. (IBP Handbook n.8).

GROSELL, M.; JENSEN, F.B. Uptake and effects of nitrite in marine teleost fish Platichthys flesus. Aquatic Toxicology, v.50, p.97-107, 2000.

HAGOPIAN, D.S.; RILEY, J.G. A closer look at the bacteriology of nitrification. Aquacultural Engineering, v.18, p.223-244, 1998.

HAMILTON, M.A. et al. Trimmed spearmam-karber method for estimating median lethal concentrations in toxicity bioassays. Environmental Science Technology, v.12, n.4, p.417, 1978.

HARGREAVES, J.A. Nitrogen biogeochemistry of aquaculture ponds. Aquaculture, v.166, p.181-212, 1998.

HECKMAN, C.W. et al. Nitrite concentration in well water from Poconé, Mato Grosso, and its relationship to public health in rural Brazil. Bulletin Environmental Contamination and Toxicology, v.58, p.8-15, 1997.

JENSEN, F.B. Nitrite disrupts multiple physiological functions in aquatic animals. Comparative Biochemistry and Physiology Part A, v.135, p.9-24, 2003.

LEWIS, W.M. JR.; MORRIS, D.P. Toxicity of nitrite to fish: a review. Transactions of the American fisheries society, v.115, n.2, p.183-195, 1986.

NIKINMAA, M. How does environmental pollution affect red cell function in fish? Aquatic Toxicology, v.22, p.227-238, 1992.
PALACHEK, R.M.; TOMASSO, J.R. Toxicity of nitrite to channel catfish (Ictalurus punctatus), tilapia (Tilapia aurea), and largemouth bass (Micropterus salmoides): evidence for a nitrite exclusion mechanism. Canadian Journal of Fisheries and Aquatic Sciences, v.41, p.1739-1744, 1984.

PERRONE, S.J.; MEADE, T.J. Protective effects of chloride on nitrite toxicity to coho salmon (Oncorhynchus kisutch). Journal of the Fisheries Research Board of Canada, v.34, p.486-492, 1977.

RUSSO, R.C.; THURSTON, R.V. The accute toxicity of nitrite to fishes. In: Tubbs, R. 1 .A editor. Recents Advances in Fish Toxicology. Corvallis, Oregon : U.S. Environmental Protection Agency, Ecological research Service, 1977. p.118-131. (EPA600/3-77-085).

SAROGLIA, M.G. et al. Acute toxicity of nitrite to sea bass (Dicentrarchus labrax) and European eel (Anguilla anguilla). Journal of the World Aquaculture Society, v.12, p.121-126, 1981.

SCARANO, G. et al. Hematological responses of sea bass Dicentrarchus labrax to sublethal nitrite exposure. Transactions of the American fisheries Society, v.113, p.360-364, 1984.

SCARANO, G.; SAROGLIA, M.G. Recovery of fish from functional and haemolytic anaemia after brief exposure to a lethal concentration of nitrite. Aquaculture, v.43, p.421-426, 1984.

SCHOORE, J.E. et al. Responses of blue catfish and channel catfish to environmental nitrite. Journal Aquatic Animal Health, v.7, p.304-311, 1995.

TAVARES, L.H.S. Limnologia aplicada à aqüicultura. Jaboticabal, SP : Funep, 1994. 70p.

VAL, A. L.; HONCZARYK, A. Criando peixes na Amazônia. Manaus, AM : INPA, 1995. 160p.

WEIRICH, C.R.; TOMASSO, J.R. Toxicity of ammonia and nitrite to sunshine bass in selected environments. Journal Aquatic Animal Health, v.5, p.64-72, 1993.

WILLIAMS, E.M.; EDDY, F.B. Cloride uptake in freshwater teleosts and its relationship to nitrite uptake and toxicity. Journal Comparative Physiology, Part B, v.156, p.867-872, 1986.

WOLFF, I.A.; WASSERMAN, A.E. Nitrates, nitrites, and nitrosamines. Science, v.177, n.4043, p.15-19, 1972. 